\title{
Emulsion Graft Polymerization of Methyl Methacrylate onto Cellulose Nanofibers
}

\author{
Hiromu Okada1, Chao Zhao', Yusuke Mizuta1, Katsumi Yoshino², Ryuichi Sugimoto' ${ }^{*}$ \\ ${ }^{1}$ School of Environmental Science and Engineering, Kochi University of Technology, Kochi, Japan \\ ${ }^{2}$ Shimane Institute for Industrial Technology, Matsue, Japan \\ Email: *sugimoto.ryuichi@kochi-tech.ac.jp
}

How to cite this paper: Okada, H., Zhao, C., Mizuta, Y., Yoshino, K. and Sugimoto, R. (2021) Emulsion Graft Polymerization of Methyl Methacrylate onto Cellulose Nanofibers. Green and Sustainable Chemistry, 11, 9-22.

https://doi.org/10.4236/gsc.2021.111002

Received: December 1, 2020

Accepted: February 1, 2021

Published: February 4, 2021

Copyright $\odot 2021$ by author(s) and Scientific Research Publishing Inc. This work is licensed under the Creative Commons Attribution International License (CC BY 4.0).

http://creativecommons.org/licenses/by/4.0/

\begin{abstract}
Methyl methacrylate (MMA) was successfully grafted onto cellulose nanofibers (CNFs) at room temperature in an emulsion system using a diethyl $(1,10-$ phenanthroline $N_{1}, N_{10}$ ) zinc(II) complex (Phen-DEZ) with oxygen as the radical initiator. The effects of reaction temperature, initiator concentration, and monomer content on the grafting reaction were investigated. The molecular weight of the non-grafted PMMA, which was produced during graft polymerization, was more than 1 million, as determined by size exclusion chromatography. The PMMA-grafted CNFs were analyzed by Fourier transform infrared spectroscopy, thermogravimetric analysis, and scanning electron microscopy, which confirmed the grafting of PMMA on the nanofiber surface. The study presents a strategy for the grafting of high-molecular weight PMMA onto CNFs in an emulsion system using Phen-DEZ and $\mathrm{O}_{2}$.
\end{abstract}

\section{Keywords}

Cellulose Nanofibers, Graft Polymerization, Methyl Methacrylate, Emulsion, Diethylzinc

\section{Introduction}

Cellulose, a polysaccharide, is the main structural component of the cell walls of many plants and is used in a variety of applications as an organic material present in abundance on Earth. Cellulose is synthesized not only by terrestrial plants, but also by marine and aquatic algae as well as bacteria such as acetic acid bacteria. Cellulose is a homopolymer composed of D-glucose molecules linearly linked by $\beta$ - $(1,4)$ glycoside linkages. Moreover, it is an environmentally benign material that is a constituent of dietary fiber and is used to produce a wide variety of products such as regenerated fiber, composites [1] [2] [3] and bioethanol 
[4] [5].

In particular, cellulose nanofibers (CNFs) are one of the functional materials that have attracted attention in recent years as a raw material for the synthesis of highly functional materials [6] [7] [8]. Research has been conducted on materials derived from CNFs for a wide range of applications, including personal care products and food. CNFs have excellent properties such as a low thermal expansion, biodegradability, and biocompatibility. In addition, CNFs are characterized by their light weight and high strength, and in practice, the strength of CNFs is 5 times that of steel although its weight is $1 / 5$ th that of steel [9] [10] [11]. In addition, the coefficient of linear expansion of CNFs is as small as that of quartz glass, and their application in various industries is being explored because of their excellent characteristics [1]. Graft copolymers are functionalized through complexation with resins and graft polymerization [12]. Among these, graft polymerization is a typical method that is widely used to effectively modify CNF properties.

The physical and chemical properties of a cellulose substrate can be changed by grafting several functional monomers onto cellulose [13]. Graft polymerization on carboxymethyl cellulose or hydroxypropyl cellulose has been reported by Kubota and Kuwabara [14]. In their work, the grafting rate was increased by adding a functional group on cellulose before grafting to increase the reactivity; however, the method requires chemical pretreatment of cellulose.

It has been reported that the graft polymerization of vinyl monomers can be performed directly on cellulose using azobis(isobutyronitrile) (AIBN) [15] or peroxide [16] as an initiator. However, to generate radicals, the reaction system needs to be heated to $70^{\circ} \mathrm{C}$ or higher, which leads to side reactions. Since cellulose has good compatibility with water, graft polymerization on cellulose is preferably carried out in an aqueous system.

Graft polymerization by Ceric ion on cellulose has been reported since the 1960s. Ceric ion (IV) is a powerful oxidizing agent for alcohols containing 1,2 glycol groups.

Thus grafting and oxidation of cellulose by Ceric ion (IV) would proceed simultaneously.

Allyl methacrylate has been grafted on cellulose at a relatively low temperature of approximately $50^{\circ} \mathrm{C}$ using a cerium salt [17].

In addition, alkyl boron is known to react with oxygen to generate radicals even at low temperatures, and graft polymerization on cotton was carried out at ambient temperature using tributylborane as an initiator [18].

Diethylzinc (DEZ) is widely used for addition to alkenes, alkynes, imines, and carbonyl compounds such as enones, ketones, and aldehydes [19] [20] [21] [22]. Since DEZ is capable of generating free radicals with oxygen at room temperature, it is a promising initiator [23] [24]. The free radicals generated from DEZ have been used for the polymerization of vinyl monomers such as styrene and methyl methacrylate (MMA) [25]. However, DEZ is extremely active and spon- 
taneously ignites in air. Moreover, it cannot be used in polar solvents such as water and methanol because it hydrolyzes immediately. The harsh reaction conditions and inconvenient operation limit the application of DEZ.

Emulsion polymerization is characterized by a high polymerization rate and high reaction yield, and the polymers synthesized in an emulsion system have a high molecular weight. Because cellulose is compatible with water, it is expected that graft polymerization on cellulose in an emulsion system will give a high graft yield. However, since DEZ is unstable to air and water, emulsion polymerization of vinyl monomers using DEZ is impossible.

DEZ is a Lewis acid and is capable of forming a complex with a Lewis base through donor-acceptor interactions. DEZ complexes can be synthesized by reacting DEZ with various types of Lewis bases such as a-imino ketones and diamines [26] [27] [28] [29]. Noltes and Hurk have reported the synthesis of a complex of DEZ with 1,10-phenanthroline (Phen) (Phen-DEZ) [30].

Although the authors did not discuss the stability of the Phen-DEZ complexes, Phen has a rigid structure with two electron-donating nitrogen atoms and forms a strong bond with the zinc atom. Therefore, DEZ is presumed to have hardly decomposed.

In fact, we have confirmed polymerization of Styrene in an aqueous System using a diethylzinc and 1,10-phenanthroline complex [31].

In this work, we report the graft polymerization of MMA onto CNFs in an emulsion system using Phen-DEZ as an initiator.

\section{Experimental}

\subsection{Materials}

DEZ was supplied by Nippon Aluminum Alkyls, Ltd. 1,10-phenanthroline (Phen), methyl methacrylate (MMA), sodium dodecyl sulfate (SDS), chloroform, acetone, methanol, and deoxygenated hexane were purchased from FUJIFILM Wako Pure Chemical Corporation. CNFs were purchased from Chuetsu Pulp \& Paper Co., Ltd. MMA was purified by distillation before use. Deionized water was used to prepare all solutions.

\subsection{Characterization and Measurements}

The infrared spectra were obtained in the range of $4000-400 \mathrm{~cm}^{-1}$ by Jasco FT/IR-480 Plus. UV-Vis spectra were obtained by measuring the diffuse reflectance of the samples on a Jasco V-650 UV-Vis spectrometer. A thermogravimetry analyzer (Hitachi, STA $7200 \mathrm{RV}$ ) was carried out to determine the thermal stability of the films. The tests were performed in air from $25^{\circ} \mathrm{C}$ to $550^{\circ} \mathrm{C}$ $\left(10^{\circ} \mathrm{C} / \mathrm{min}\right)$ at a flow rate of $25 \mathrm{~mL}^{-1}$. Size-exclusion chromatography (SEC) was performed with a Jasco PU-2080 Plus pump, a TOSOH UV-8020 detector. $\mathrm{CHCl}_{3}$ was used as the eluent. Raman spectra were obtained on an HR800 Horiba Raman spectrometer. The surface morphology of the cotton fiber was examined using field emission (FE)-SEM (Hitachi SU-8020). Atomic force micro- 
scope (AFM, Nanoscope II, Digital Instruments) was used to analyze the morphology of the grafted PP films.

\subsection{Preparation of Diethyl(1,10-phenanthroline $\left.N_{1}, N_{10}\right)$ zinc(II) Complex (Phen-DEZ)}

We used the same method reported in one of our previously published papers to synthesize Phen-DEZ [31]. All the reactions in this work were carried out in an oven-dried Schlenk flask with a stopcock under an argon atmosphere. DEZ (6 $\mathrm{mmol})$ was slowly dropped into Phen $(6 \mathrm{mmol})$ in hexane $(15 \mathrm{~mL})$, and the reaction mixture was stirred for $24 \mathrm{~h}$ at $23^{\circ} \mathrm{C}$ under argon gas. After the reaction was complete, the reddish-orange product was collected by filtration and dried overnight in vacuo. As determined by $1 \mathrm{H}-\mathrm{NMR}$ spectroscopy analysis in benzene-d6, the obtained diethyl(1,10-phenanthroline $\left.N_{1}, N_{10}\right)$ zinc(II) complex was a 1:1 complex of DEZ and Phen [31].

\subsection{Graft Polymerization Procedure}

The emulsion was prepared by following a previously reported method [31]. First, SDS $(0.70 \mathrm{mmol})$ was dissolved in deaerated deionized water $(10 \mathrm{ml})$. Then, MMA (15 mmol) was dropped into the SDS solution to prepare an emulsion. The emulsion was then added to a flask containing CNFs (50 $\mathrm{mg}$ ) and the Phen-DEZ complex $(0.3,0.15,0.10,0.075$, and $0.06 \mathrm{mmol})$ and oxygen as an initiator was fed in the required amount to initiate the reaction. The graft polymerization was carried out under an inert gas atmosphere from $23^{\circ} \mathrm{C}$ to $70^{\circ} \mathrm{C}$ for 2 $\mathrm{h}$. The reaction was terminated by adding excess methanol. The PMMA-grafted CNFs were separated from PMMA by suction filtration. The obtained product was washed with methanol to remove ungrafted MMA by filtration.

The free (ungrafted) PMMA homopolymer was removed from the reaction mixture by solvent extraction in a Soxhlet extractor using chloroform. The PMMA-grafted CNFs were dried under vacuum for $12 \mathrm{~h}$. The grafted CNFs and the ungrafted PMMA homopolymer are hereinafter referred to as PMMA-g-CNF and PMMA homopolymer, respectively. The grafting ratio and the free PMMA ratio were determined by the following formulas.

$$
\begin{gathered}
\text { Grafting yield }(\%)=\frac{\text { weight of }(\text { grafted CNF }- \text { original CNF })}{\text { weight of original CNF }} \times 100(\%) \\
\text { Homopolymer yield }(\%)=\frac{\text { weight of PMMA }}{\text { weight of MMA }} \times 100(\%) \\
\text { Grafting efficiency }(\%)=\frac{\text { weight of grafted PMMA }}{\text { weight of }(\text { grafted PMMA + homopolymer })} \times 100(\%)
\end{gathered}
$$

The yield and molecular weight of the extracted PMMA homopolymer were measured, and PMMA-g-CNF was analyzed by Fourier transform infrared (FT-IR) spectroscopy, thermogravimetric analysis (TGA), and scanning electron microscopy (SEM). 


\section{Results and Discussion}

The graft copolymerization of PMMA on CNFs was carried out under the conditions described in the experimental section (Scheme 1).

Table 1 summarizes the results of graft polymerization performed under various reaction conditions.

The graft polymerization of MMA onto CNFs was carried out from $23^{\circ} \mathrm{C}$ to $70^{\circ} \mathrm{C}$.

Phen-DEZ can initiate graft polymerization at relatively low temperatures compared with the commonly used initiators such as AIBN and benzoyl peroxide, which require high reaction temperatures.

Figure 1 shows the effect of temperature on the grafting yield and grafting efficiency. At a reaction temperature of $23^{\circ} \mathrm{C}$, since the amount of radicals produced on the cellulose is insufficient, the homopolymerization reaction mainly proceeds instead of graft polymerization. On the other hand, with an increase in reaction temperature to $50^{\circ} \mathrm{C}$, the rate of radical generation and the dynamic energy of the monomer molecules increase, which increase both the grafting yield and grafting efficiency due to the diffusion of monomer molecules on the polymer main chain. The grafting yield and grafting efficiency in the graft polymerization of acrylic acid by ceric ammonium nitrate has been reported to be similarly affected by the graft temperature [32].

C N F

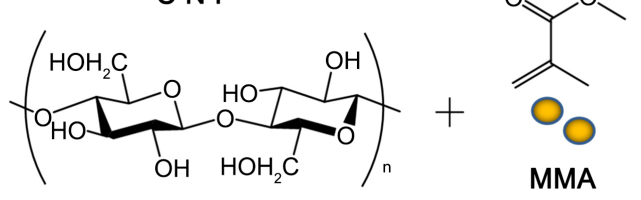

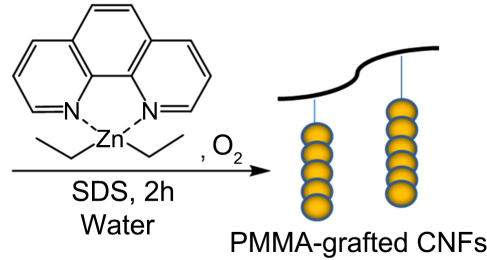

Scheme 1. The graft polymerization of MMA onto CNFs using Phen-DEZ.

Table 1. Results of graft copolymerization of CNF and MMA.

\begin{tabular}{|c|c|c|c|c|c|c|c|}
\hline Entry & Temp. $\left({ }^{\circ} \mathrm{C}\right)$ & MMA:Initiator & $\begin{array}{c}\text { Grafting Yield } \\
(\%)\end{array}$ & $\begin{array}{l}\text { Homopolymer } \\
\text { Yield (\%) }\end{array}$ & $\begin{array}{c}\text { Grafting } \\
\text { Efficiency (\%) }\end{array}$ & $\mathrm{Mw}\left(\times 10^{6}\right)$ & PDI \\
\hline 1 & 23 & $50: 1$ & 1.1 & 61 & 0.06 & 1.3 & 2.3 \\
\hline 2 & 40 & $50: 1$ & 0.63 & 51 & 0.63 & 1.0 & 1.9 \\
\hline 3 & 50 & $50: 1$ & 16 & 88 & 0.98 & 1.0 & 2.6 \\
\hline 4 & 60 & $50: 1$ & 7.3 & 68 & 1.2 & 1.5 & 2.0 \\
\hline 5 & 70 & $50: 1$ & 2.0 & 89 & 0.086 & 1.3 & 2.1 \\
\hline 6 & 50 & 100:1 & 13 & 64 & 1.4 & 2.5 & 2.6 \\
\hline 7 & 50 & $150: 1$ & 11 & 52 & 1.7 & 2.1 & 2.6 \\
\hline 8 & 50 & $200: 1$ & 9.6 & 63 & 1.0 & 2.7 & 2.9 \\
\hline 9 & 50 & 250:1 & 9.6 & 26 & 2.2 & 2.0 & 2.6 \\
\hline
\end{tabular}




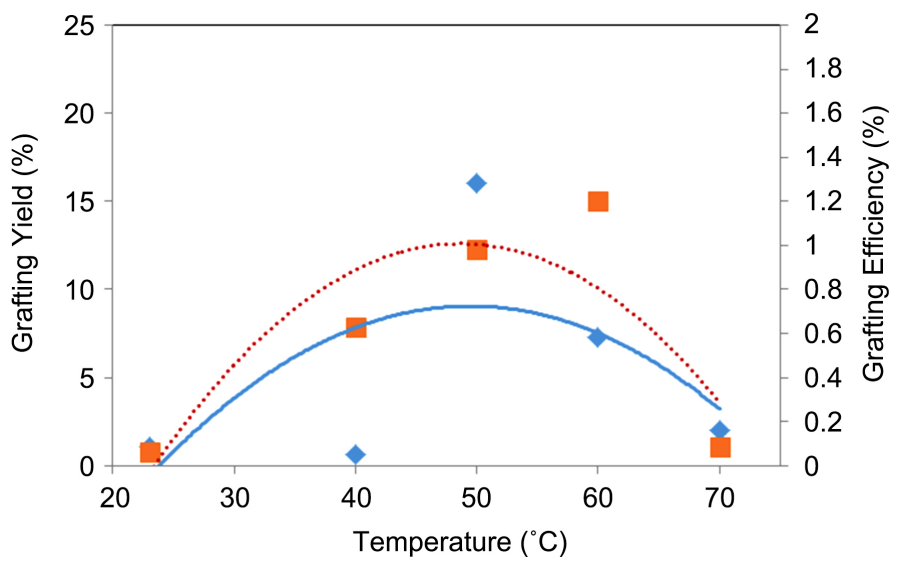

Figure 1. Effect of temperature on graft polymerization: $\downarrow$ Grafting Yield; Grafting Efficiency.

With a further increase in temperature to $70^{\circ} \mathrm{C}$, both the grafting yield and grafting efficiency decreased, and were almost the same as those obtained at $23^{\circ} \mathrm{C}$. At $70^{\circ} \mathrm{C}$, the reaction between radicals tends to occur more frequently, and the concentration of radicals involved in the graft copolymerization decreased due to an increase in chain-transfer reaction and termination reaction.

Figure 2 shows the effect of the temperature on the ungrafted PMMA. With an increase in temperature, the yield of the homopolymer improved; however, the molecular weight did not change much.

The FT-IR spectra of the CNF and PMMA-g-CNF samples synthesized at different temperatures are displayed in Figure 3. The results confirm the graft polymerization of PMMA on CNFs. The characteristic peaks of cellulose are observed at $2899 \mathrm{~cm}^{-1}$ and $3250-3500 \mathrm{~cm}^{-1}$, which are associated with the $\mathrm{C}-\mathrm{H}$ and O-H stretching vibrations, respectively [33] [34] [35]. The prominent peaks attributed to cellulose are observed in the range of $1314-1372 \mathrm{~cm}^{-1}$ corresponding to the $\mathrm{C}-\mathrm{H}$ and $\mathrm{C}-\mathrm{O}$ bending vibrations. The FT-IR spectrum of the graft polymer shows a peak at $1732 \mathrm{~cm}^{-1}$ that is due to the $\mathrm{C}=\mathrm{O}$ stretching vibration of the ester groups of grafted PMMA. The weak characteristic absorption band at $1275 \mathrm{~cm}^{-1}$ corresponds to the $\mathrm{C}-\mathrm{O}$ stretching vibration in PMMA. The appearance of $\mathrm{C}=\mathrm{O}$ stretching vibration peak proved that MMA was grafted onto the CNFs.

The ratio of MMA to initiator was varied from 250:1 (0.4\%) to 50:1 (2\%) under the same conditions except that the temperature was set as $50^{\circ} \mathrm{C}$, which is considered an appropriate temperature for the graft polymerization of MMA on the CNFs.

Figure 4 shows the effect of radical concentration on the grafting yield and grafting efficiency. The grafting yield increased with an increase in radical concentration, probably because the amount of radicals generated on cellulose increased due to an increase in radical concentration. However, the grafting efficiency hardly changed with increasing radical concentration, possibly because side reactions were promoted with an increase in the amount of radicals. 


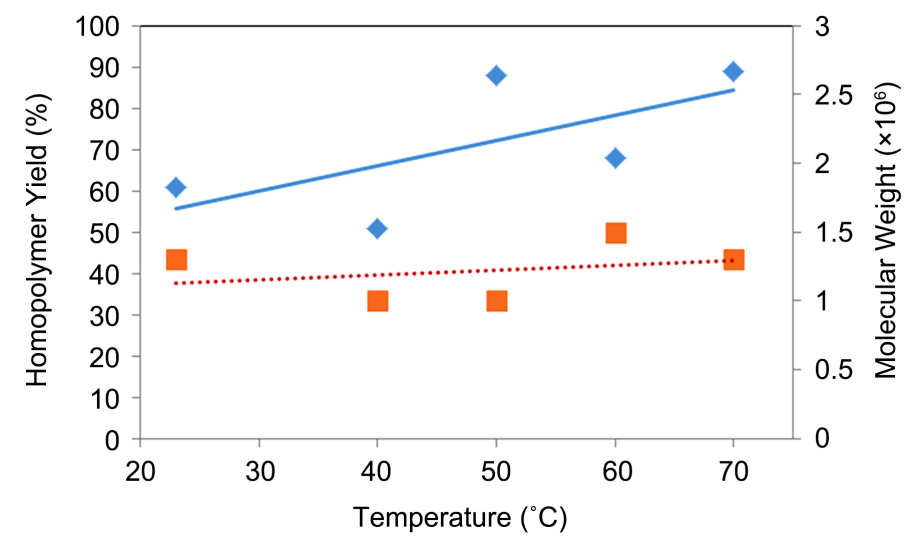

Figure 2. Effect of temperature on homopolymerization: $\diamond$ Yield; $\square$ Molecular Weight.

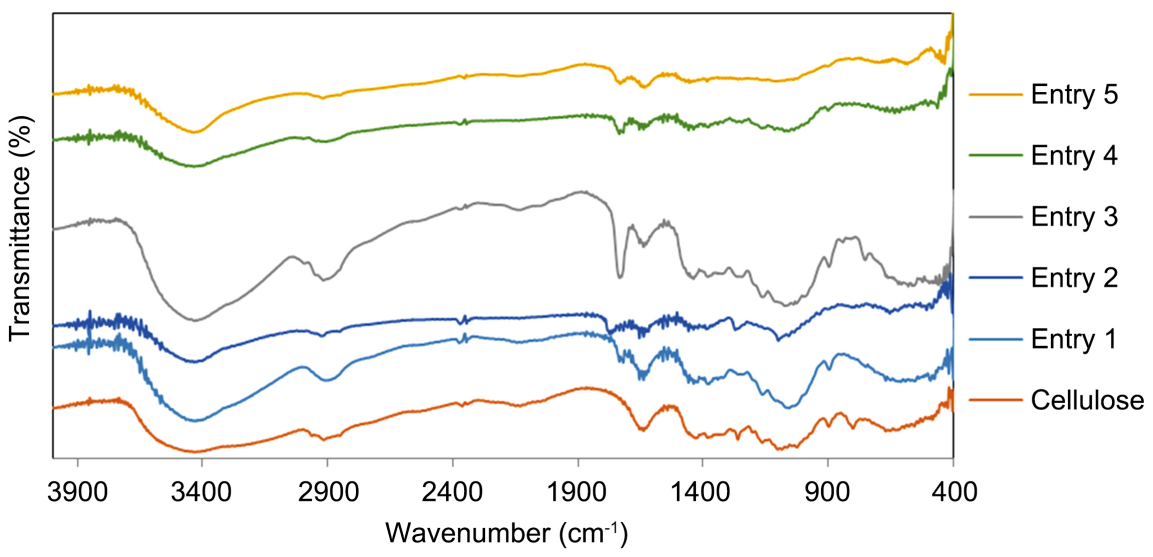

Figure 3. FT-IR spectra of pristine CNFs and grafted CNFs.

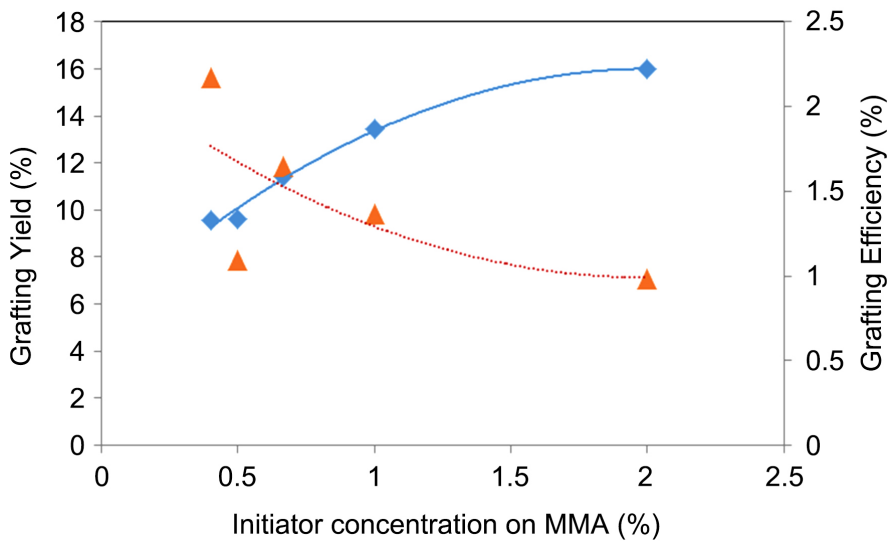

Figure 4. Effect of initiator concentration on graft polymerization: $\diamond$ Grafting Yield; $\Delta$ Grafting Efficiency.

Figure 5 shows the effect of initiator concentration on the homopolymer yield and molecular weight. Generally, with a decrease in initiator concentration, the molecular weight increases, while the yield decreases. Both the yield and molecular weight changed significantly with the initiator concentration. This is because with an increase in initiator concentration to a certain extent, much of the 
initiator was used to initiate graft polymerization. On the other hand, at low initiator concentrations, side reactions could not occur easily; hence, the molecular weight was significantly high at low initiator concentrations.

Figure 6 shows the FT-IR spectra of pristine CNFs and PMMA-g-CNFs (Entry 2, 6 - 9). As discussed in Figure 3, the $\mathrm{C}=\mathrm{O}$ peak appeared around 1750 $\mathrm{cm}-1$, which proved that MMA was grafted onto the CNFs. It can be seen from Figure 6 that, with an increase in graft yield, the carbonyl peak intensity gradually increased.

Figure 7 shows the TGA curves of CNFs, PMMA, and PMMA-g-CNFs. Pristine CNFs started to decompose at around $300^{\circ} \mathrm{C}$ and decomposed quickly up to $350^{\circ} \mathrm{C}$. Beyond $350^{\circ} \mathrm{C}$, the rate of thermal decomposition decreased. Thus, the thermal decomposition behavior of CNFs is similar to that of cellulose. When the temperature reached $400^{\circ} \mathrm{C}$, PMMA was almost completely decomposed. Similar to PMMA, the decomposition of PMMA-g-CNF started at $300^{\circ} \mathrm{C}$. This is thought to be the effect of grafted PMMA. However, above $350^{\circ} \mathrm{C}$, the decomposition rate decreased similar to that of CNFs. The TGA results show that PMMA-g-CNF has the characteristics of both of PMMA and CNFs.

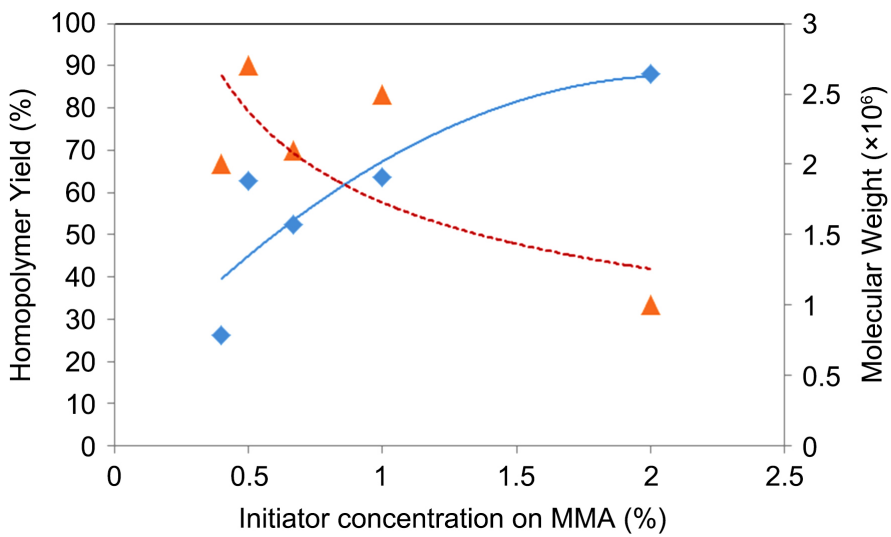

Figure 5. Effect of initiator concentration on homopolymerization: $\diamond$ Yield; $\triangle$ Molecular Weight.

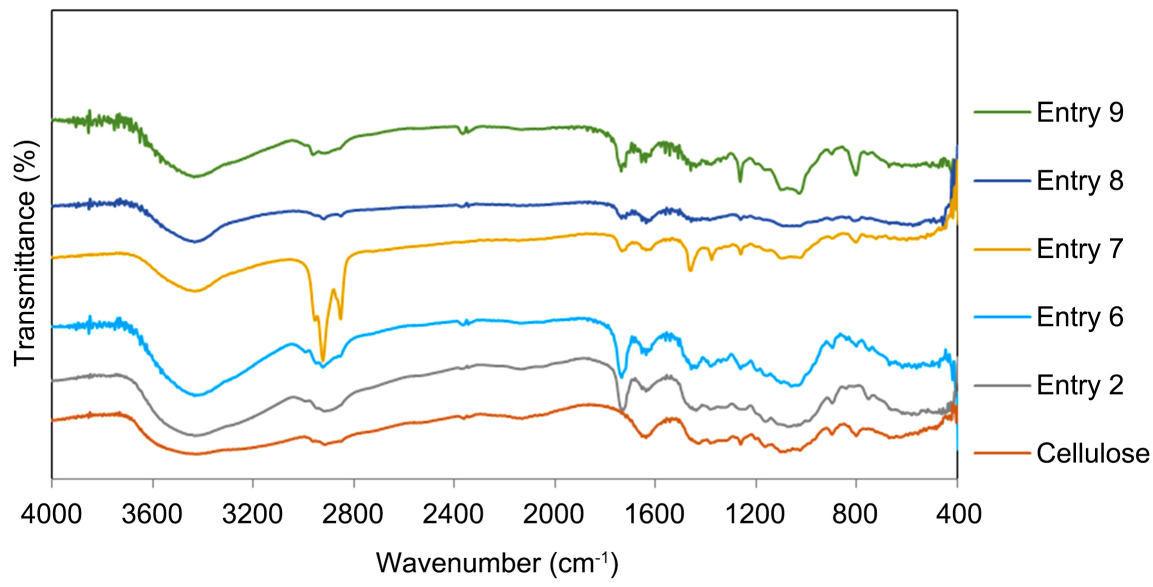

Figure 6. FT-IR spectra of pristine CNFs and PMMA-g-CNFs (Entry 2, 6 - 9). 
SEM was performed to examine the changes in the surface morphology of CNFs caused by graft polymerization. The SEM images (Figure 8) show that the CNFs have a diameter of approximately $20-30 \mathrm{~nm}$. As can be seen in Figure 8(d) and Figure 8(e), the grafted PMMA (the white part) is localized. This can be explained by the following considerations. Under the reaction conditions, the concentration of SDS in water was $0.02 \mathrm{~g} / \mathrm{mL}$. It has been reported that micelles with an average particle size of $110 \mathrm{~nm}$ were obtained using 9-BBN as a polymerization initiator and an SDS concentration of $0.03 \mathrm{~g} / \mathrm{mL}$ [36]. This suggests that some CNFs were present inside the micelles. Moreover, the portion grafted onto

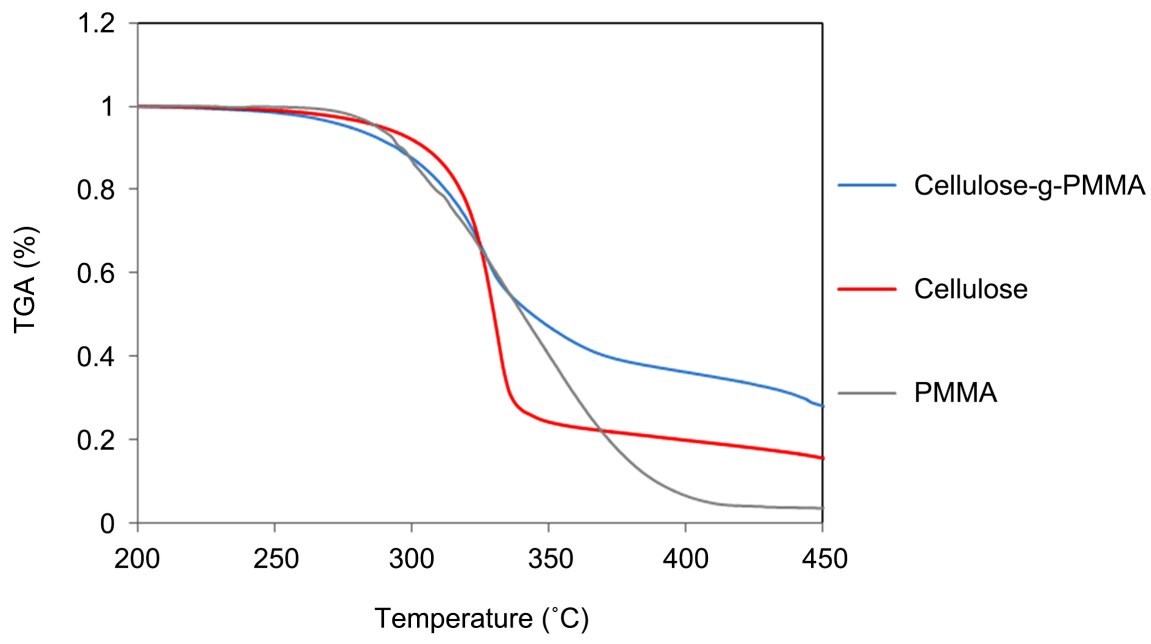

Figure 7. TGA curves of CNFs, PMMA, and PMMA-g-CNFs.

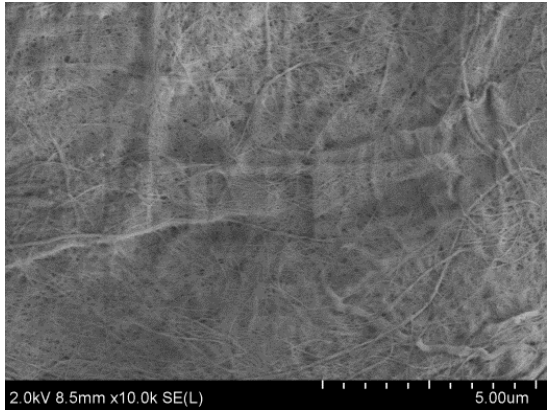

(a)

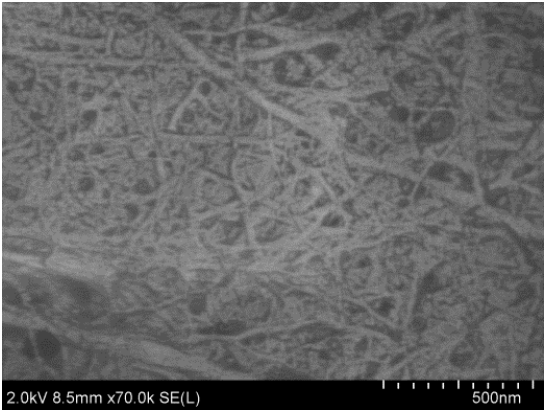

(b)

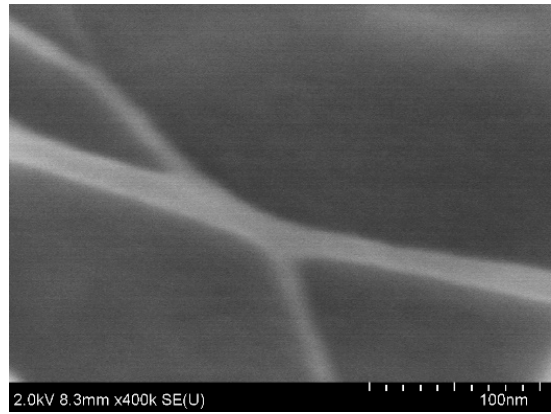

(c)

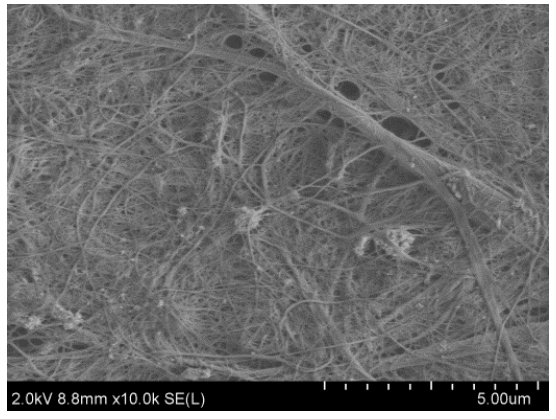

(d)

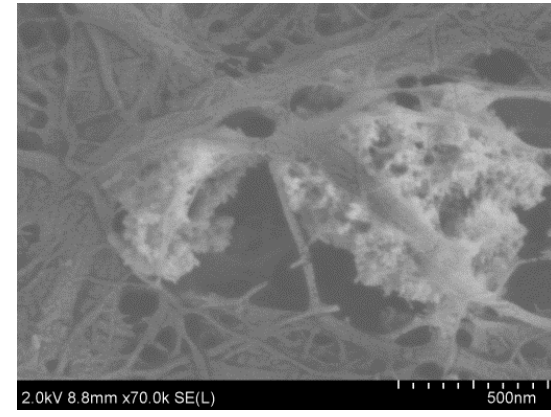

(e)

Figure 8. SEM images of (a), (b), (c) CNFs and (d), (e) PMMA-g-CNFs. 
the CNFs is considered to be the portion of the micelles. El-Naggar reported that at low levels of grafting, it is difficult to distinguish between the grafted and ungrafted surfaces of the fiber, and that the polymer is locally grafted onto the substrate at a certain level of grafting [37]. Based on these findings, it was considered that the graft polymerization of PMMA progressed locally rather than on the entire CNF surface.

The reaction mechanism of graft polymerization was considered to proceed as shown in Scheme 2. Ethyl radicals and ethoxy radicals were generated by the reaction of DEZ with oxygen. These radicals reacted with $\mathrm{C} 6$ position of the cellulose, initiating the graft polymerization of MMA. Wei et al. grafted polyhydroxybutyrate onto the C6 position of cellulose, as confirmed by electron spin resonance spectroscopic analysis. This is because the $\mathrm{C} 6$ position is more flexible and movable than C1-C5 positions [39] [40].

(a) Initiation
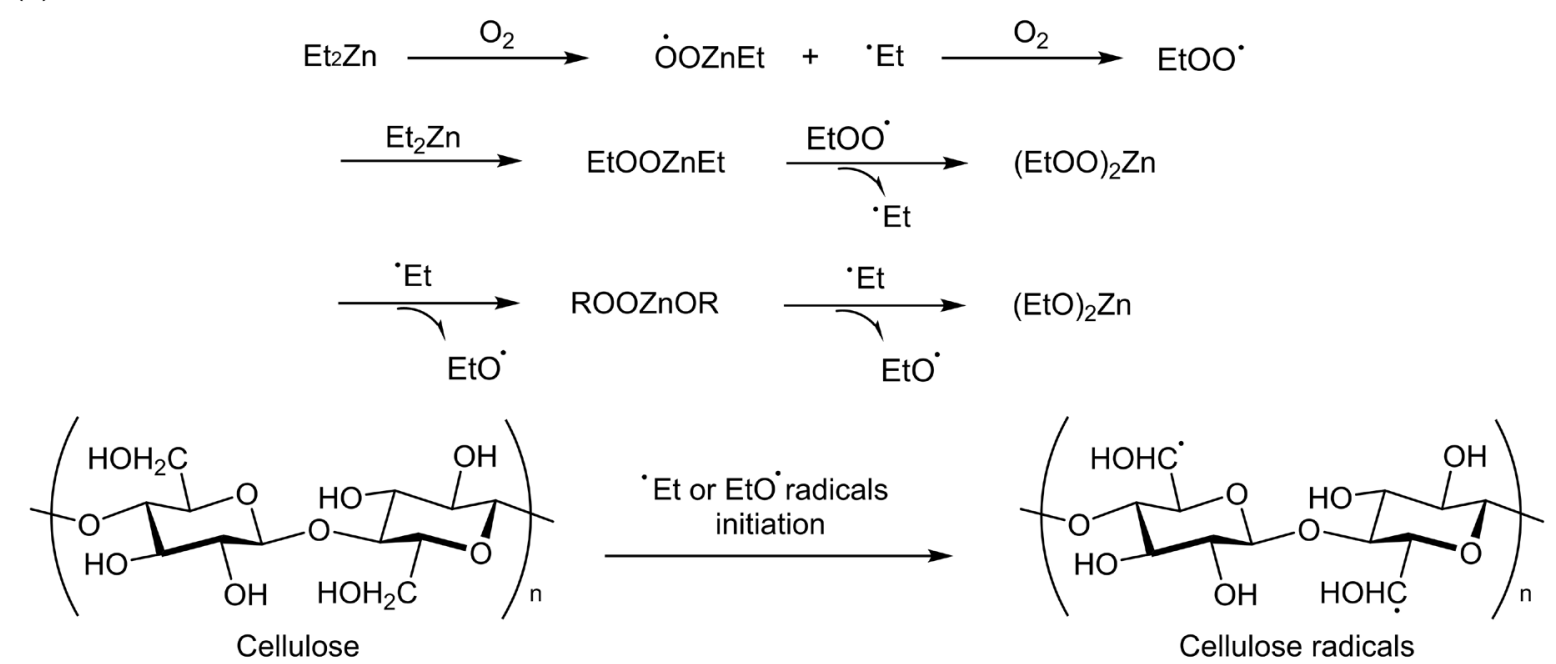

(b) Growth reaction

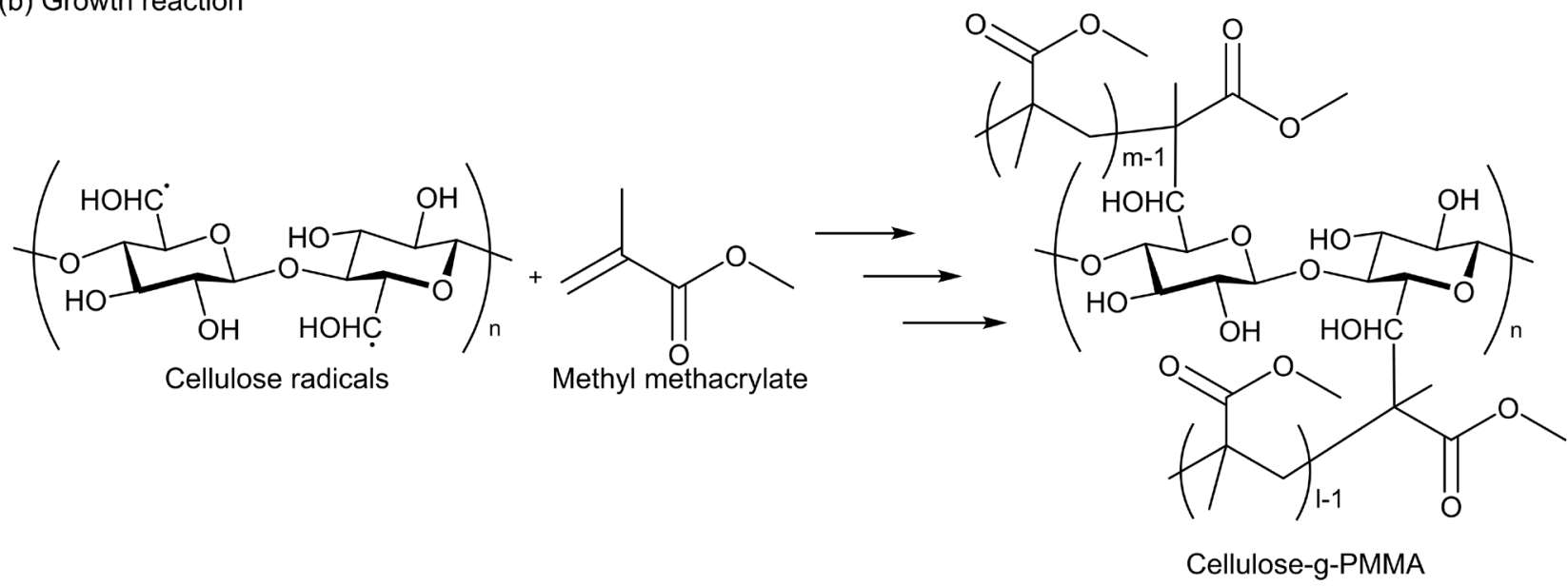

Scheme 2. Reaction mechanism of DEZ-initiated grafting of MMA onto cellulose: [38] [39]. (a) Radical initiation and (b) Growth reaction. 


\section{Conclusion}

The emulsion graft polymerization of PMMA onto CNFs was performed using a diethyl(1,10-phenanthroline $\left.N_{1}, N_{10}\right)$ zinc(II) complex (Phen-DEZ) as an initiator. The graft polymerization was confirmed by FT-IR spectroscopy, TG-DTA, and SEM analyses as well as by the changes in the CNF weight before and after modification. It was found that the reaction could be carried out under mild conditions, and the grafted polymer had a relatively high molecular weight. The current results suggest that temperature is the most important factor affecting the graft system. The optimum temperature for graft copolymerization under the given conditions was $50^{\circ} \mathrm{C}$.

\section{Acknowledgements}

Authors thank Yoshihiko Kambara, Kiyoshi Takahashi and Kouki Fukumura for their technical support and helpful discussions.

\section{Conflicts of Interest}

The authors declare no conflicts of interest regarding the publication of this paper.

\section{References}

[1] Nishino, T., Matsuda, I. and Hirao, K. (2004) All-Cellulose Composite. Macromolecules, 37, 7683-7687. https://doi.org/10.1021/ma049300h

[2] Wambua, P., Ivens, J. and Verpoest, I. (2003) Natural Fibres: Can They Replace Glass in Fibre Reinforced Plastics? Composites Science and Technology, 63, 1259-1264. https://doi.org/10.1016/S0266-3538(03)00096-4

[3] Bledzki, A.K. and Gassan, J. (1999) Composites Reinforced with Cellulose Based Fibres. Progress in Polymer Science, 24, 221-274. https://doi.org/10.1016/S0079-6700(98)00018-5

[4] Klinke, H.B., Thomsen, A.B. and Ahring, B.K. (2004) Inhibition of Ethanol-Producing Yeast and Bacteria by Degradation Products Produced during Pre-Treatment of Biomass. Applied Microbiology and Biotechnology, 66, 10-26. https://doi.org/10.1007/s00253-004-1642-2

[5] Selim, K.A., El-Ghwas, D.E., Easa, S.M. and Hassan, M.I.A. (2018) Bioethanol a Microbial Biofuel Metabolite; New Insights of Yeasts Metabolic Engineering. Fermentation, 4, 16-27. https://doi.org/10.3390/fermentation4010016

[6] Nogi, M., Iwamoto, S., Nakagaito, A.N. and Yano, H. (2009) Optically Transparent Nanofiber Paper. Advanced Materials, 21, 1595-1598.

https://doi.org/10.1002/adma.200803174

[7] Moon, R.J., Martini, A., Nairn, J. Simonsen, J. and Youngblood, J. (2011) Cellulose Nanomaterials Review: Structure, Properties and Nanocomposites. Chemical Society Reviews, 40, 3941-3994. https://doi.org/10.1039/C0CS00108B

[8] Fukuzumi, H., Saito, T., Iwata, T., Kumamoto, Y. and Isogai, A. (2009) Transparent and High Gas Barrier Films of Cellulose Nanofibers Prepared by TEMPO-Mediated Oxidation. Biomacromolecules, 10, 162-165. https://doi.org/10.1021/bm801065u

[9] Page, D.H. and El-Hosseiny, F. (1983) The Mechanical Properties of Single Wood 
Pulp Fibres. Part VI, Fibril Angle and the Shape of the Stress-Strain Curve. Journal of Pulp and Paper Science, Transactions of the Technical Section, 9, TR 99-100.

[10] Sakurada, I., Nukushina, Y. and Ito, T. (1962) Experimental Determination of the Elastic Modulus of Crystalline Regions in Oriented Polymers. Journal of Polymer Science, 57, 651-660. https://doi.org/10.1002/pol.1962.1205716551

[11] Nakagaito, A.N. and Yano, H. (2004) The Effect of Morphological Changes from Pulp fiber towards Nano-Scale fibrillated Cellulose on the Mechanical Properties of High-Strength Plant Fiber Based Composites. Applied Physics A, 78, 547-552. https://doi.org/10.1007/s00339-003-2453-5

[12] Borner, H.G. and Matyjaszewski, K. (2002) Graft Copolymers by Atom Transfer Polymerization. Macromolecular Symposia, 177, 1-16. https://doi.org/10.1002/1521-3900(200201)177:1\%3C1::AID-MASY1\%3E3.0.CO;2$\underline{\mathrm{V}}$

[13] Bhattacharya, A. and Misra, B.N. (2004) Grafting: A Versatile Means to Modify Polymers Techniques, Factors and Applications. Progress in Polymer Science, 29, 767-814. https://doi.org/10.1016/j.progpolymsci.2004.05.002

[14] Kubota, H. and Kuwabara, S. (1997) Cellulosic Absorbents for Water Synthesized by Grafting of Hydrophilic Vinyl Monomers on Carboxymethyl Cellulose. Journal of Applied Polymer Science, 64, 2259-2263.

https://doi.org/10.1002/(SICI)1097-4628(19970613)64:11\%3C2259::AID-APP21\%3 E3.0.CO;2-Y

[15] Misra, B.N., Jassal, J.K. and Pande, C.S. (1978) Grafting onto Cellulose. II. AIBNand BPO Initiated Grafting of Poly(Vinyl Acetate). Journal of Polymer Science: Polymer Chemistry Edition, 16, 295-297.

[16] Chauhan, G.S., Kumar, S., Verma, M. and Sharma, R. (2005) Graft Copolymers of Poly(Methyl Methacrylate) on Cellulose and Their Use as Supports in Metal Ion Sorption. Polymers \& Polymer Composites, 13, 105-116. https://doi.org/10.1177\%2F096739110501300109

[17] El-Alfy, E.A., Khalil, M.I. and Hebeish, A.A. (1981) Ce(IV)-Induced Polymerization of Allyl Methacrylate with Cotton Cellulose. Journal of Polymer Science: Polymer Chemistry Edition, 19, 3137-3143. https://doi.org/10.1002/pol.1981.170191208

[18] Kojima, K., Iwabuchi, S., Murakami, K., Kojima, K. and Ichikawa, F. (1972) The Grafting of Methyl Methacrylate onto Cotton by Tri-n-Butylborane. Journal of Applied Polymer Science, 16, 1139-1148. https://doi.org/10.1002/app.1972.070160508

[19] Soai, K., Yokoyama, S., Hayasaka, T. and Ebihara, K. (1988) Catalytic Asymmetric Induction in Enantioselective Conjugate Addition of Dialkylzincs to Enones. The Journal of Organic Chemistry, 53, 4148-4149. https://doi.org/10.1021/jo00252a063

[20] Negishi, E., VanHorn, D.E., Yoshida, T. and Rand, C.L. (1983) Selective Carbon-Carbon Bond Formation via Transition Metal Catalysis. 31. Controlled Carbometalation. 15. Zirconium-Promoted Carbozincation of Alkynes. Organometallics, 2, 563-565. https://doi.org/10.1021/om00076a021

[21] Bhupathy, M. and Cohen, T. (1985) Remarkable Stereocontrol in the Addition of an Anion to an a-Alkoxyaldehyde by Encouraging or Discouraging Internal Complexation. Applications to Brief Syntheses of the Mus Musculus (House Mouse) Pheromone and Exo-Brevicomin. Tetrahedron Letters, 26, 2619-2622. https://doi.org/10.1016/S0040-4039(00)98118-8

[22] Soai, K., Hatanaka, T. and Miyazawa, T. (1992) Highly Enantioselective Alkylation of Carbon-Nitrogen Double Bonds. Catalytic and Stoichiometric Asymmetric Synthesis of Optically Active Amines by the Enantioselective Addition of Dialkylzinc Re- 
agents to $N$-Diphenylphosphinoylimines. Journal of the Chemical Society, Chemical Communications, 16, 1097-1098. https://doi.org/10.1039/C39920001097

[23] Lewinski, J., Sliwinski, W., Dranka, M., Justyniak, I. and Lipkowski, J. (2006) Reactions of $[\mathrm{ZnR} 2(\mathrm{~L})]$ Complexes with Dioxygen: A New Look at an Old Problem. Angewandte Chemie International Edition, 45, 4826-4829. https://doi.org/10.1002/anie.200601001

[24] Maury, J., Feray, L., Bazin, S., Clement, J.-L., Marque, S.R.A., Siri, D. and Bertrand, M.P. (2011) Spin-Trapping Evidence for the Formation of Alkyl, Alkoxyl, and Alkylperoxyl Radicals in the Reactions of Dialkylzincs with Oxygen. Chemistry-A European Journal, 17, 1586-1595. https://doi.org/10.1002/chem.201002616

[25] Nakayama, Y., Tsuruta, T. and Furukawa, J. (1960) Reactivity of Organometallic Compounds in Olefin Polymerization. V. The Co-Catalytic Action of Oxygen on the Vinyl Polymerization Induced by Organometallic Compounds. Die Makromolekulare Chemie, 40, 79-90. https://doi.org/10.1002/macp.1960.020400107

[26] Van Vliet, M.R.P., Jastrzebski, J.T.B.H., Van Koten, G., Vrieze, K. and Spek, A.L. (1983) Novel Reactions of Substituted 1-Aza-4-oxobutadienes ( $\alpha$-Iminoketones) with Diorganozinc Reagents. Selective Ethyl Transfer in the Et2Zn/t-BuNC(H)C(Me)O System and X-Ray Crystal Structure of $[\mathrm{EtZn}(\mathrm{Et})(\mathrm{T}-\mathrm{Bu}) \mathrm{NC}(\mathrm{H}) \mathrm{C}(\mathrm{Me}) \mathrm{O}] 2$. Journal of Organometallic Chemistry, 251, c17-c21. https://doi.org/10.1016/0022-328X(83)80256-3

[27] Wissing, E., Rijnberg, E., Van der Schaaf, P.A., Van Gorp, K., Boersma, J. and Van Koten, G. (1994) A Comparative Study of Thermal- and Radiation-Induced Single Electron Transfer in Reactions of 1,4-Diaza-1,3-butadienes with Dialkylzinc Compounds. Organometallics, 13, 2609-2615. https://doi.org/10.1021/om00019a018

[28] Van der Kerk, G.J.M. (1972) Organozinc Coordination Chemistry and Catalytic Effects of Organozinc Coordination Compounds. Pure and Applied Chemistry, 30, 389-408. https://doi.org/10.1351/pac197230030389

[29] El-Shazly, M.F. (1978) Electrochemical Reduction and Electron Spin Resonance Studies of Organozinc Complexes. Inorganica Chimica Acta, 26, 173-176. https://doi.org/10.1016/S0020-1693(00)87209-6

[30] Noltes, J.G. and Van Den Hurk, J.W.G. (1965) Investigations on Organozinc Compounds: II. Synthesis and Absorption Spectra of Some 2,2'-Bipyridine and I,10-Phenanthroline Complexes of Organozinc Compounds. Journal of Organometallic Chemistry, 3, 222-228. https://doi.org/10.1016/S0022-328X(00)87503-8

[31] Zhao, C., Okada, H. and Sugimoto, R. (2018) Polymerization of Styrene in Aqueous System Using a Diethylzinc and 1,10-Phenanthroline Complex. Polymer, 154, 211-217. https://doi.org/10.1016/j.polymer.2018.09.019

[32] Singha, A. and Rana, A. (2011) Kinetics of Graft Copolymerization of Acrylic Acid onto Cannabis indica Fibre. Iranian Polymer Journal, 20, 913.

[33] Vieira, J.G., Oliveira, G.D.C., Filho, G.R., Assunção, R.M.N., Meireles, C.D.S., Cerqueira, D.A., Silva, W.G. and Motta, L.A. (2009) Production, Characterization and Evaluation of Methylcellulose from Sugarcane Bagasse for Applications as Viscosity Enhancing Admixture for Cement Based Material. Carbohydrate Polymers, 78, 779-783. https://doi.org/10.1016/j.carbpol.2009.06.016

[34] Khalil, H.P.S.A., Ismail, H., Rozman, H.D. and Ahmad, M.N. (2001) The Effect of Acetylation on Interfacial Shear Strength between Plant Fibres and Various Matrices. European Polymer Journal, 37, 1037-1045. https://doi.org/10.1016/S0014-3057(00)00199-3

[35] Higgins, H.G., Stewart, C.M. and Harrington, K.J. (1961) Infrared Spectra of Cellu- 
lose and Related Polysaccharides. Journal of Polymer Science, 51, 59-84. https://doi.org/10.1002/pol.1961.1205115505

[36] Zhao, C., Sugimoto, R. and Naruoka, Y. (2018) Simple Method for Synthesizing Ultra-High-Molecular-Weight Polystyrene through Emulsion Polymerization Using Alkyl-9-BBN as an Initiator. Chinese Journal of Polymer Science, 36, 592-597. https://doi.org/10.1007/s10118-018-2064-4

[37] El-Naggar, A.M., El-Hosamy, M.B., Zahran, A.H. and Zondy, M.H. (1992) Surface Morphology/Mechanical/Dyeability Properties of Radiation-Grafted Sisal Fibers. American Dyestuff Reporter, 81, 40-44.

[38] Sakata, R., Tsuruya, T., Saegusa, T. and Furukawa, J. (1960) Polymerization of Propylene Oxide and Vinyl Compounds by Diethylzinc in the Presence of Cocatalysts. Die Makromolekulare Chemie, 40, 64-78. https://doi.org/10.1002/macp.1960.020400106

[39] Wei, L., McDonald, A.G. and Stark, N.M. (2015) Grafting of Bacterial Polyhydroxybutyrate (PHB) onto Cellulose via In Situ Reactive Extrusion with Dicumyl Peroxide. Biomacromolecules, 16, 1040-1049.

https://doi.org/10.1021/acs.biomac.5b00049

[40] Wei, L. and McDonald, A.G. (2016) A Review on Grafting of Biofibers for Biocomposites. Materials, 9, 303-325. https://doi.org/10.3390/ma9040303 